\title{
Comparative analysis of immune related genes between domestic pig and germ- free minipig
}

\author{
Ju Young Lee ${ }^{1,2 \dagger}$, Sang Eun Kim ${ }^{3 \dagger}$, Hoon Taek Lee ${ }^{3}$ and Jeong Ho Hwang ${ }^{1 *}$
}

\begin{abstract}
Recently, minipig has been considered as an animal model that is appropriate for human disease model to study toxicology, pharmacology, and xenotransplantation. Nevertheless, minipigs are bred in various environment according to their use. Here, we suggest that minipigs used for research should be bred in well-controlled facility, comparing immune status of pigs raised in different breeding environment. DNA microarray was performed with ear skin and placenta of Landrace domestic pigs (DPs) and Minnesota germ-free minipigs (GPs). Their immune transcriptome was analyzed by gene ontology (GO) annotation database, based on criteria of $\mid \log _{2}$ fold change $\geq 1$ with $P \leq 0.05$. As a result, we found that immune related genes in the ear skin of DPs were highly activated, compared to GPs. On the other hand, no significant s were found in the placenta. Quantitative real-time PCR (qRT$P C R$ ) was performed in five candidate immune genes. Their fold changes were consistent with the results from DNA microarray $(P \leq 0.05)$. In conclusion, we experimentally proved that porcine immune system was affected by different breeding environment, suggesting the importance of controlling microbes in animal room for the qualified research.
\end{abstract}

Keywords: Minipig, Germ-free facility, Differentially expressed gene, Systemic immune activation

\section{Introduction}

Experimental animal models have been considered as important research tool to conduct preclinical study and identify human disease mechanism. The species of animal model have been also diversified, such as rodents, non-rodents, and non-human primates [1]. In general toxicity test, one species of non-rodents is essentially required to meet Good Laboratory Practice (GLP) guideline [2]. However, arguments to utilize those animals for research have been constantly raised due to ethical issues and lacks of experiment reproducibility [3]. To overcome these problems, the minipig has been raised as

\footnotetext{
* Correspondence: Jeongho.Hwang@kitox.re.kr

† Ju Young Lee and Sang Eun Kim contributed equally to this work.

${ }^{1}$ Animal Model Research Group, Korea Institute of Toxicology, 30, Baekhak

1-gil, Jeongeup-si, Jeollabuk-do 143-701, South Korea

Full list of author information is available at the end of the article
}

an alternative animal due to similarity of pathological features with human, and being relatively free from animal ethic issues. The advantages of utilizing minipig are as follows [4]. First, the minipig is relatively free from animal ethic issue than other animals because of their industrial use as the livestock in human society. Second, the minipig has been improved for proper size to be managed and bred easier than traditional farm pigs, which enables to reduce economic costs incurred by securing breeding space for installment of cages and their feed consumption. In addition, these features produce reliable data for researcher by increasing the number of animals in experiment. Finally, the minipig shares similar histological and physiological characteristics with human, which makes them as standard resource for xenotransplantation. Despite these advantages, it is highly necessary to breed minipigs in the well-controlled

(c) The Author(s). 2020 Open Access This article is licensed under a Creative Commons Attribution 4.0 International License, which permits use, sharing, adaptation, distribution and reproduction in any medium or format, as long as you give appropriate credit to the original author(s) and the source, provide a link to the Creative Commons licence, and indicate if changes were made. The images or other third party material in this article are included in the article's Creative Commons licence, unless indicated otherwise in a credit line to the material. If material is not included in the article's Creative Commons licence and your intended use is not permitted by statutory regulation or exceeds the permitted use, you will need to obtain permission directly from the copyright holder. To view a copy of this licence, visit http://creativecommons.org/licenses/by/4.0/ The Creative Commons Public Domain Dedication waiver (http://creativecommons.org/publicdomain/zero/1.0/) applies to the data made available in this article, unless otherwise stated in a credit line to the data. 
facility such as Specific Pathogen Free or Germ-free grade [5]. Immunogen, such as bacteria, in the conventional facility could bring out infection and induce activation of immune response, which leads to affect experiment data. Moreover, a recent report warns of transmission of zoonotic disease from porcine organ to human patient through xenotransplantation [6].

Thus, it should be experimentally identified that immunological change of pigs in different breeding environment for researchers to perform safe and qualified experiments. We chose ear skin, primary immunological barrier against external environment, as target tissue [7]. Placenta known for immune privilege region was chosen as control tissue to confirm endogenous variation caused by immunological feature of tissues [8]. Transcriptome profiling and comparative analysis between domestic pigs (DPs) and germ-free minipigs (GPs) were performed using DNA microarray and quantitative real-time PCR (qRT-PCR).

\section{Methods/experimental}

\section{Animals}

A pregnant Minnesota minipig raised in sterile condition (Laboratory Animal Research Center in Konkuk University, Seoul, Korea) was randomly selected from pregnant sows. The facility continuously maintained positive pressure with HEPA-filtered air, and temperature $\left(22 \pm 2{ }^{\circ} \mathrm{C}\right)$ and humidity $(50 \pm 5 \%)$. Newborn germ-free piglets (3 males and 1 females; $n=4$ ) were produced by hysterectomy of pregnant sow under aseptic conditions. Average body weights of the piglets ranged from 450 to $550 \mathrm{~g}$. They were transferred to the aseptic isolator $(1200 \mathrm{~W} \times$ $900 \mathrm{D} \times 950 \mathrm{H} \mathrm{m} / \mathrm{m}$, SK-ISO1700HBP600; Three-shine Inc., Daejeon, Korea), and fed sterilized soy bean milk (Fig. 1a). The procedures that contained animal welfare and ethical problem were approved by the Konkuk University Institutional Animal Care and Use Committee (IACUC; approval number: KU01410). A pregnant Landrace pig raised in conventional condition (Dongsan

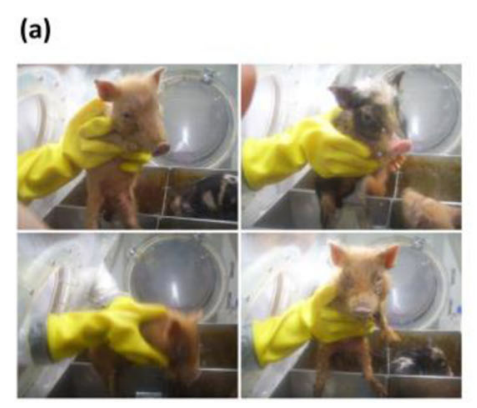

(d)

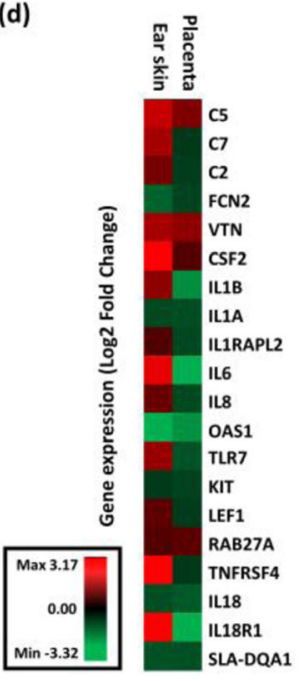

(b)

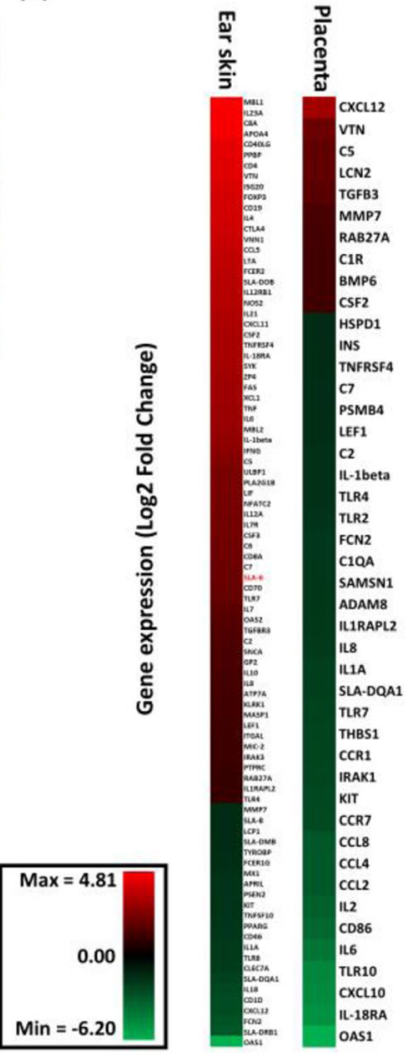

(c)
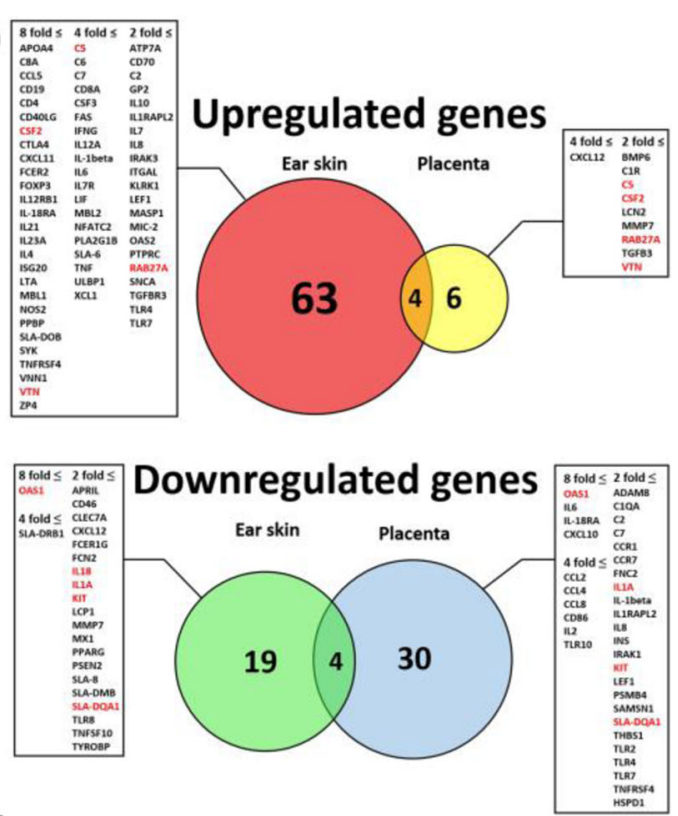

(e)

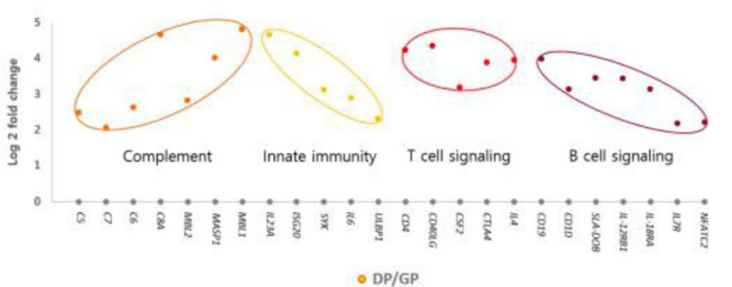

Fig. $1 \mathrm{Imm}$ unological transcriptome profile of pigs. a Pictures of Germ-free piglets born in sterile isolator. $\mathbf{b}$ Heatmap for comparison of immune related genes in ear skin and placenta. Each fold change was calculated by comparing domestic pigs (DPs) with germ-free minipigs (GPs). $\mathbf{c}$ Venn Diagram showing up and down-regulation of immune-related genes in DPs compared to GPs. The number of genes and gene symbols are described in each circle and box. Genes having same expression pattern in both tissues are marked as red color. $\mathbf{d}$ Heatmap for comparing pattern of immune-related genes commonly expressed in both tissues. e Process of systemic immune activation of DPs. The same colored dots are grouped by same signaling pathway. The Y-axis indicates the log2 fold change of relative gene expression in DPs compared to GPs. The Xaxis indicates gene symbol 
Farm, Younchun, Gyunggido, Korea) was also selected from pregnant sows. The average body weights of domestic piglets ( 3 males and 1 females; $n=4$ ) ranged from 1.05 to $1.25 \mathrm{~kg}$. All breeding process for the piglets were performed under same condition with that for Germfree piglets except controlling microbial environment.

\section{RNA sample preparation}

Chorion parts of placenta $(n=4)$ were specifically collected and frozen with liquid nitrogen immediately at birth. Ear skins of germ-free piglets $(n=4)$ were obtained in the aseptic isolator on 3 weeks after birth. To prevent RNA degradation, frozen placenta samples are emerged in $1 \mathrm{ml}$ of a RNAlater-ICE (Ambion, Invitrogen Carlsbad, CA, USA) solution and incubated in $4{ }^{\circ} \mathrm{C}$ for over-night. Total RNA was extracted from the ear skins and the placentas by using Phenol/Chloroform extraction method. All RNA samples were pooled for DNA microarray. Reverse transcription reaction for qRT-PCR was performed with a QuantiNova Reverse Transcription Kit (QIAGEN Science Inc., Germantown, MD, USA).

\section{DNA microarray and gene ontology analysis}

DNA microarray was performed using Porcine (v2) Gene expression $4 \times 44 \mathrm{~K}$ microarray (Cat.no G2519F-025440; Agilent technology, Santa Clara, CA, USA) covered with 43,803 probes in capable of detecting every porcine gene. The procedure was followed by technical manual of SurePrint Gene Expression Array (Agilent technology). Quality check of RNA samples was performed using Agilent 2100 Bioanlayzer (Agilent technology). Gene Ontology (GO) was analyzed by using DAVID Bioinformatics Resources 6.87 [9].

\section{Quantitative real-time PCR}

qRT-PCR was performed in $20 \mu \mathrm{l}$ PCR reaction mixtures that included 2x iQ SYBR Green Supermix (Bio-rad Laboratories. Hercules, CA, USA, each primer at a concentration of $0.5 \mu \mathrm{M}$, and template cDNA according to the manufacturer's protocol. it was run in a QuantStudio 5 Real-Time PCR System (Applied Biosystmes, Foster city, CA, USA) using the amplification parameters: the initial denaturation step at $95^{\circ} \mathrm{C}$ for $3 \mathrm{~min}$ was followed by 40 cycles of denaturation at $95^{\circ} \mathrm{C}$ for $20 \mathrm{~s}$, annealing and elongation at $60^{\circ} \mathrm{C}$ for $1 \mathrm{~min}$ without the final elongation step. Gene expression level of Glyceraldehyde 3phosphate dehydrogenase (GAPDH) was used for an endogenous control to normalize each RNA samples. All primer sequences are shown in Table 1 [10-15]. $2^{-\Delta \Delta \mathrm{Ct}}$ method was used for the relative quantification of target genes.

\section{Statistical analysis}

All samples for qRT-PCR was run in triplicate and result graph was expressed as means \pm S.D. The $P$ value was determined using Student's t test. Pearson's correlation coefficient was used to measure statistical relationship between $\mathrm{qRT}-\mathrm{PCR}$ and DNA microarray.

\section{Results}

\section{Summary of DNA microarray data}

A total of 13,673 and 3599 differentially expressed genes (DEGs) were found in each ear skin and placenta $(P<$ $0.05, \quad \mid \log _{2}$ fold $\left.\mid \geq 1\right)$. Of total DEGs, we classified immune-related genes to confirm immunological difference between DPs and GPs. As a result, 90 and 44 genes were found in each ear skin and placenta (Fig. 1b). Specific information was provided in Table S1.

Table 1 Primers used for quantitative real-time PCR

\begin{tabular}{|c|c|c|c|}
\hline Gene symbol $^{1}$ & Primer sequences (from 5 ' to $3^{\prime}$ ) & Length (bp) & Gene Bank ID \\
\hline \multirow[t]{2}{*}{ OAS1 } & F: AGAGTCCACGACGGGAGAACC & 111 & MG799562.1 \\
\hline & R: ACTGACCCAGGGCATCAAAGG & & \\
\hline \multirow[t]{2}{*}{ CD40LG } & F: ATTCACTTGGGCGGAGTCTTC & 80 & HQ110108.1 \\
\hline & R: GTGGCTCACTTGGCTTGGAT & & \\
\hline \multirow[t]{2}{*}{ IL-1B } & F: GAAGTGATGGCTAACTACGGTGAC & 108 & NM_214055.1 \\
\hline & R: TCTCAGAGAACCAAGGTCCAGGT & & \\
\hline \multirow[t]{2}{*}{ IL-6 } & F: AAAGAATCCAGACAAAGCCACC & 83 & NM_001252429.1 \\
\hline & R: TCCACTCGTTCTGTGACTGCA & & \\
\hline \multirow[t]{2}{*}{ |L-18R1 } & F: ATGATTATGTTTTGGAGTTIT & 373 & NM_214098.1 \\
\hline & R: GTAATATTGAAGGTTITGGTGA & & \\
\hline \multirow[t]{2}{*}{ GAPDH } & F: GCTACACTGAGGACCAGGTTG & 294 & NM_001206359.1 \\
\hline & R: AGGAGATGCTCGGTGTGTTG & & \\
\hline
\end{tabular}


(a)
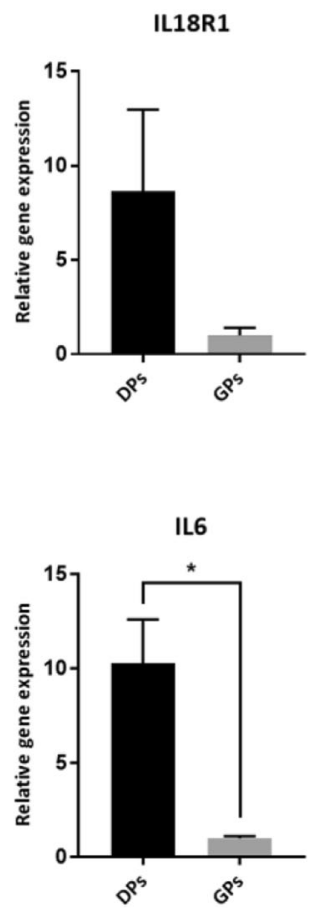

Ear skin

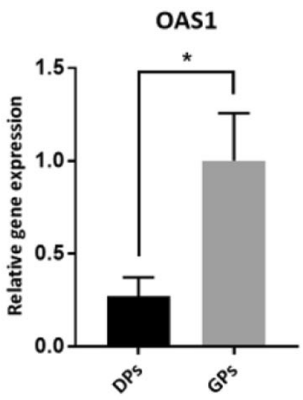

CD4OLG

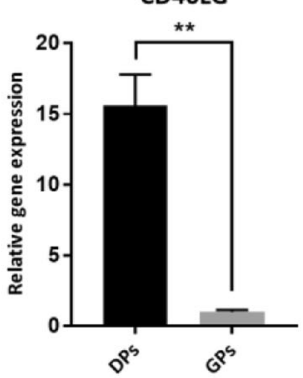

Placenta

IL6
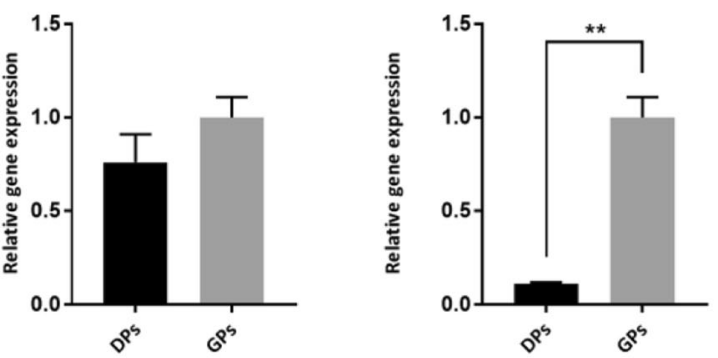

(b)

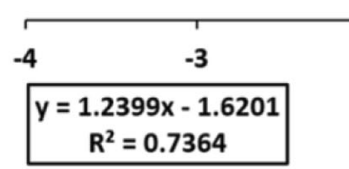

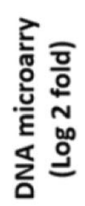
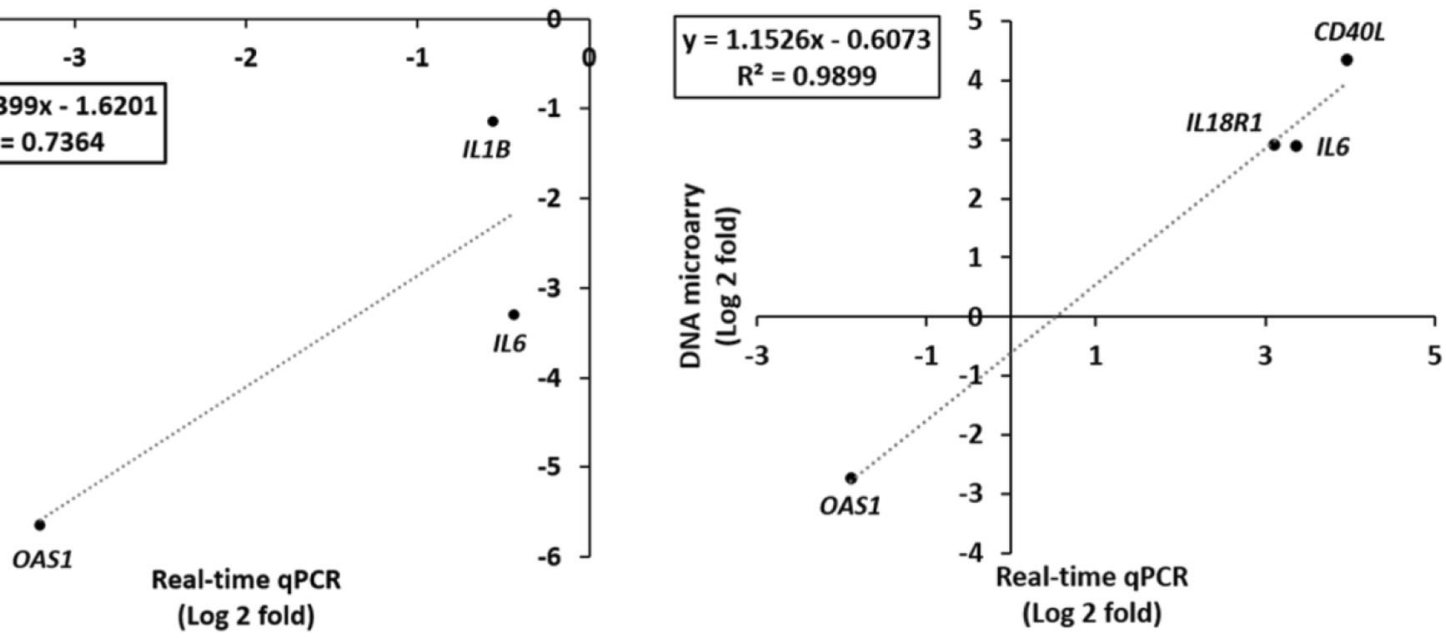

Fig. 2 Validation for fold change of DEG in DNA microarray data. a qRT-PCR results of candidate genes. Y-axis indicates fold change of gene expression. All samples are run in triplicate. All data are shown as means \pm standard deviation. $\mathbf{b}$ Correlation graph between relative expression of candidate gene from results of qRT-PCR and DNA microarray in the ear skin and the placenta. ${ }^{*} P \leq 0.05 ;{ }^{*} P \leq 0.01$

Comparison of immune related genes in the ear skin and placenta of DP compared to GP

First, we found that the number of up-regulated genes in the ear skin $(67 / 73)$ was about 7 times greater than that in the placenta (10/73), compared DPs with GPs.
However, no significant differences were found in comparison result of down-regulated genes between ear skin (23/53) and placenta (34/53) (Fig. 1c). In addition, we also sorted out 20 immune related genes that were commonly expressed in both tissues for accurate 
comparison. As a result, the number of up-regulated genes in ear skin $(14 / 20)$ about 3 times greater than that in placenta $(4 / 20)$, showing adverse pattern between two tissues (Fig. 1d). Thus, it could be expected that the DPs was infected with pathogens under conventional condition, resulting in immune activation.

\section{Systemic immune activation in DP}

Furthermore, we performed clustering analysis using DNA microarray data of the ear skin to confirm systemic immune activation. Immune related genes were grouped by biological functions that associated with a process of systemic immune activation. Thus, 22 genes were divided into 4 groups (Complement, Innate immunity, T cell signaling, B cell signaling; (Fig. 1e). This result indicated that immune activation was systemically occurred in the body of DPs.

\section{Validation of DEG data by using quantitative real-time PCR}

qRT-PCR was performed with five candidate genes including Interleukin 18 receptor alpha (IL-18R1), Cluster of differentiation 40 ligand $(C D 4 O L G)$ for ear skin, Interleukin 1 beta $(I L-1 B)$ for placenta, Interleukin 6 (IL-6), and $2^{\prime}-5^{\prime}$-Oligoadenylate synthetase 1 (OAS1) to validate DNA microarray result. As a result, the fold changes of all candidate genes were highly consistent with DNA microarray results (Fig. 2a). Moreover, we calculate correlation coefficient to measure significance of a linear relationship between qRT-PCR and DNA microarray. In conclusion, expression pattern of candidate genes in the ear skin and placenta were highly correlated (Fig. 2b). Specific gene expression result was provided in Table S2.

\section{Discussion}

Our analysis results demonstrated that porcine immune system was affected by microbes in breeding environment. The number of immune-related genes in the ear skin was greater than that in the placenta, which meant that intense immunological changes occur in the marginal tissue (Fig. 1b). We also could verify different expression patterns in placenta, implicating that unidentified mechanism suppress aggressive immune response to prevent its fetus from being killed [16, 17]. According to recent study, it was identified that specific mechanism of immune tolerance between maternal endothelium and fetal tissues during pregnancy [8].

Contrary to expectations, the expression patterns of some genes were not consistent with our conclusion. These results might be explained by the fact that differences of expression value were too small to be statistically significant (Ras-related protein Rab-27A (RAB27A), Interleukin 1 beta $(I L-1 B)$, KIT proto-oncogene, receptor tyrosine kinase (KIT), and MHC class II histocompatibility antigen SLA-DQA (SLA-DQA1)). In addition, homologous expression pattern of Colony stimulating factor 2 (CSF2), Vitronectin $(V T N)$, and $O A S 1$ in both ear skin and placenta or increased expression of immune genes in the placenta of germ-free minipigs have not been clearly explained. However, some studies reported that expression of some immune genes in placenta could be unexpected because of variable reasons, such as epigenetic modification and its unique microenvironment $[18,19]$. In addition, pregnant mice raised in conventional and germfree environment represented different immunological adaptations [20]. These studies suggested that un identified immune modulation were occurred during pregnancy.

\section{Conclusions}

In spite of some experimental limitations, we identified that uncontrolled breeding facility could spoil immune system of experimental animals. Clinically, porcine skin have been well known for good model in toxicology studies due to its similarity of histological structure and skin immune system with human [21]. This study could support the idea that researchers should breed minipigs in the bacteria-controlled facility to perform qualified animal experiment.

\section{Supplementary Information}

The online version contains supplementary material available at https://doi. org/10.1186/s42826-020-00077-7

Additional file 1: Supplementary table 1. Summary of DEGs from DNA microarray data.

Additional file 2: Supplementary table 2. Gene information of systemic immune activation.

\section{Abbreviations}

DP: Domestic pig; GP: Germ free minipig; GO: Gene ontology; GLP: Good laboratory practice; qRT-PCR: Quantitative real-time PCR; DEG: Differentially expressed gene; IL-18R1: Interleukin 18 receptor alpha; CD40LG: Cluster of differentiation 40 ligand; IL-6: Interleukin 6; OAS1: 2'-5-Oligoadenylate synthetase 1; RAB27A: Ras-related protein Rab-27A; KIT: KIT proto-oncogene, receptor tyrosine kinase; SLA-DQA1: MHC class II histocompatibility antigen SLA-DQA; CSF2: Colony stimulating factor 2; VTN: Vitronectin; IL-

1B: Interleukin 1 beta

\section{Acknowledgments}

Not applicable

\section{Authors' contributions}

$H T L$ and $J H H$ designed the study; JYL and SEK performed experiments; JYL and SEK analyzed and interpreted the experimental results; JYL wrote original draft and prepared the table and figures; JYL and JHH edited and revised manuscript. All authors approved the final version of the manuscript

\section{Funding}

This work was supported by the Korea Institute of Toxicology (KIT, Korea) grant funded by the Ministry of science and ICT (MIST, Korea). [Project number: KK-1911].

\section{Availability of data and materials}

All experiment data during this study are included in this manuscript and supporting files. 


\section{Competing interests}

The authors declare that they have no competing interests.

\section{Author details}

'Animal Model Research Group, Korea Institute of Toxicology, 30, Baekhak 1-gil, Jeongeup-si, Jeollabuk-do 143-701, South Korea. ${ }^{2}$ Division of Human and Environmental Toxicology, University of Science \& Technology, Daejeon, South Korea. ${ }^{3}$ Department of Stem Cell and Regenerative Biotechnology, Konkuk University, 120 Neungdong-ro, Gwangjin-gu, Seoul 05029, Republic of Korea.

Received: 6 October 2020 Accepted: 18 November 2020

Published online: 01 December 2020

\section{References}

1. Ganderup NC, Harvey W, Mortensen JT, Harrouk W. The minipig as nonrodent species in toxicology--where are we now? Int J Toxicol. 2012; 31(6):507-28.

2. Helen P, Paul B, de Lolke H, Downes N, Jones K, Cassen EM, Kimber I. Reviewing the utility of two species in general toxicology related to drug development. Int J Toxicol. 2018;37(2):121-4.

3. Hartung T. Thoughts on limitations of animal models. Parkinsonism Related Disord. 2008;14(Suppl 2):S81-3.

4. Vodicka P, Smetana K, Dvoránková B, Emerick T, Xu YZ, Ourednik J, Ourednik $\checkmark$, Motlík J. The miniature pig as an animal model in biomedical research. Ann N Y Acad Sci. 2005;1049:161-71.

5. Safron J, Gonder JC. The SPF pig in research. ILAR J. 1997;38(1):28-31.

6. Niu D, Wei HJ, Lin L, Geroge H, Wang T, Lee $I H$, Zhao HY, Wang $Y$, Kan $Y$, Shrock E, Lesha E, Wang G, Luo Y, Qing Y, Jiao D, Zhao H, Zhhou X, Wnag S, Wei H, Güell M, Church GM, Yang L. Inactivation of porcine endogenous retrovirus in pigs using CRISPR-Cas9. Science. 2017;357(6357):1303-7.

7. Prescott SL, Larcombe DL, Logan AC, West C, Burks W, Caraballo L, Levin M, Etten VE, Horwitz P, Kozyrskyj A, Campbell DE. The skin microbiome: impact of modern environments on skin ecology, barrier integrity, and systemic immune programming. World Allergy Organ J. 2017;10(1):29.

8. Gobert M, Lafaille JJ. Maternal-fetal immune tolerance, block by block. Cell. 2012;150(1):7-9.

9. Huang DW, Sherman BT, Lempicki RA. Bioinformatics enrichment tools:paths toward the comprehensive functional analysis of large gene lists. Nucleic Acids Res. 2009;37(1):1-13.

10. de Goffau MC, Lager S, Sovio U, Gaccioli F, Cook E, Peacock SJ, Parkhill J, Charnock-Jones DS, Smith GCS. Human placenta has no microbiome but can contain potential pathogens. Nature. 2019;572(7769):329-34.

11. Geraldes P, Gagnon S, Hadjadj S, Merhi Y, Sirois MG, Cloutier I, Tanguay JF. Estradiol blocks the induction of CD40 and CD40L expression on endothelial cells and prevents neutrophil adhesion: an ERalpha-mediated pathway. Cardiovasc Res. 2006;71(3):566-73.

12. Meijer RI, Hoevenaars FPM, Serné EH, Yudkin JS, Kokhuis TJA, Weijers EM, Hinsbergh WWMV, Smulders YM, Eringa EC. JNK2 in myeloid cells impairs insulin's vasodilator effects in muscle during early obesity development through perivascular adipose tissue dysfunction. Am J Physiol Heart Circ Physiol. 2019:317(2):H364-74.

13. Nagai $Y$, Watanabe $K$, Aso H, Ohwada S, Muneta Y, Yamaguchi T. Cellular localization of IL-18 and IL-18 receptor in pig anterior pituitary gland. Domest Anim Endocrinol. 2006;30(2):144-54.

14. Whyte JJ, Meyer AE, Spate LD, Benne JA, Cecil R, Samuel MS, Murphy CN, Prather RS, Geisert RD. Inactivation of porcine interleukin-1 beta results in failure of rapid conceptus elongation. Proc Natl Acad Sci U S A. 2018;115(2): 307-12.

15. Zheng S, Zhu D, Lian X, Liu W, Cao R, Chen P. Porcine 2', 5'-oligoadenylate synthetases inhibit Japanese encephalitis virus replication in vitro. J Med Virol. 2016;88(5):760-8.

16. Svensson-Arvelund J, Ernerudh J, Buse E, Cline JM, Haeger JDDD, Markert UR, Pfarrer C, Vos PD, Faas MM. The placenta in toxicology. Part II: systemic and local immune adaptations in pregnancy. Toxicol Pathol. 2014;42(2):32738.

17. Alijotas-Reig J, Llurba E, Gris JM. Potentiating maternal immune tolerance in pregnancy: a new challenging role for regulatory T cells. Placenta. 2014; 35(4):241-8.

18. Tomlinson MS, Bommarito PA, Martin EM, Smeester L, Fichorova RN, Onderdonk AB, Kuban KCK, O'Shea TM, Fry RC. Microorganisms in the human placenta are associated with altered CpG methylation of immune and inflammation-related genes. PLoS One. 2017;12(12):e0188664.

19. Parnell LA, Briggs CM, Cao B, Delannoy-Bruno O, Schrieffer AE, Mysorekar IU. Microbial communities in placentas from term normal pregnancy exhibit spatially variable profiles. Sci Rep. 2017;7:11200.

20. Faas M, Liu Y, Borghuis T, Loo-Bouwman C, Harmsen H, de Vos P. Microbiota induced changes in the immune response in pregnant mice. Front immunol. 2020;10:2976.

21. Summerfield A, Meurens F, Ricklin ME. The immunology of the porcine skin and its value as a model for human skin. Mol Immunol. 2015;66(1):14-21.

\section{Publisher's Note}

Springer Nature remains neutral with regard to jurisdictional claims in published maps and institutional affiliations.
Ready to submit your research? Choose BMC and benefit from:

- fast, convenient online submission

- thorough peer review by experienced researchers in your field

- rapid publication on acceptance

- support for research data, including large and complex data types

- gold Open Access which fosters wider collaboration and increased citations

- maximum visibility for your research: over $100 \mathrm{M}$ website views per year

At BMC, research is always in progress.

Learn more biomedcentral.com/submissions 